\title{
The Distribution in International Marketing - Correlation between International and Local Channels in Kosovo
}

\author{
Hidajet Karaxha PhD candidat \\ hidajeti_21@hotmail.com
}

Halit Karaxha PhD candidat

halitkaraxhaekonomik@hotmail.com

Prof. Dr. llia KRISTO

ilia. kristo@yahoo.com

\begin{abstract}
Absract
Nowadays, with all these turbulent markets, the international channels are becoming more and more important. The motivation of channel members is an important characteristic in building the relations between international and local channels. The distribution channels in countries in transition can be spread and not effective. Therefore an adequate design of the firm's strategies about marketing should be responsible for the changes between distribution channels in different countries. Sometimes this can require the delegation of marketing functions beyond national affiliates in businesses activities in promoting prices and making the products available for consumers in different countries. The globalization of markets is a phenomenon that has received great attention and is being broadly debated in all levels. In every process of globalization, the distribution of products and services between and inside local industrial markets is very important. The globalization of markets and the reorganization of distribution are interdependent processes that include changes in markets structures. In enhanced national markets, kosovar companies in order to satisfy customer requirements try to specialize the distribution levels of products and services treated with increased pressure to develop a communication in countries of the region and Europe, in dissemination of information that ease the free flow of information and products in national and international borders. This paper contains empirical data that were collected through questionnaires and interviews, and secondary data as well based on reviewing the existing literature about international distribution - the correlation between national and local channels. The final compilation of the questionnaire, the methodology and the sample were realized by analyzing the determining factors that affect the distribution in international markets. The research was realized with the owners, directors, managers and other company holders in Kosovo. The methods that were used in this paper were quantitative and qualitative methods. The sample is intentional (not probable).
\end{abstract}

Keywords: international marketing, international distribution channels, the design of international channels, the motivation of the international and local channel members.

\section{International marketing}

The international marketing includes business activities designed to plan, to stir up fares, to direct the goods and services of the company for the consumers in different states. (Cateora PH \& Gilly M. \& Graham J 2011, p. 10). Many companies face the severe competition which is more global and potential in learning international activities, finding their individual clients and widening their aspirations as a result of a global approach in the international marketing (Mühlbacher $\mathrm{H}$. \& Leihs H. \& Dahringerp L. , 2006, P. 41). According to an approved proposal by AMA (American Marketing Association) the international marketing is a multinational planning process and the execution of concepts, fares, promotion and dissemination of ideas, goods and services to create exchanges in the individual and organizational level (Onkvisit S. \& Shaë J. 2004, p. 3). 


\section{International channels of distribution}

The international marketing includes the performing of business activities designed to plan, to stir up fares, to direct the goods and services of the company for the consumers in different states. (Cateora PH \& Gilly M. \& Graham J 2011, p. 10). The international specialists of marketing are conducted by a wide range of channel alternatives. The cooperation of effective channel systems between and inside different markets, presents a difficult challenge conducted by a lot of mediators. At the other extreme, the distribution channels at countries in development can be spread, not effective or doesn't exist at all (Kotler Ph. , Armstrong G. , 2011, p. 354). A challenge of managing an international business is the direct investments in operations in other countries. Many companies first start in the field of international marketing, gain experience and gradually changing their tactics of international marketing in the field of research with the developed plans. Despite the means that are used to enter a foreign market, a company can make a small investment or none at all, which means that its involvement in the marketing can be limited to sell a product (Cateora PH \& Gilly M. \& Graham J 2011, p. 19). The companies are fully engaged to get involved in the international activities of marketing. These companies are after markets in the whole world to sell their products that are a planned result. This planning doesn't include only the marketing, but also the production of goods outside the international markets (Cateora PH \& Gilly M. \& Graham J 2011, p. 21). The analysis of distribution channels in contemporary conditions consists in correlation between economic operators from all the levels of production and distribution to the customer's door. This means that the relations should be built not only with customers but with the main suppliers and mediators as well (Segetlija Z. \& Mesarić J. \& Dujak D. ,2011,p. 793). The international channels of marketing are becoming more and more important. The satisfaction of channel members is a main characteristic in the relations between international and local channels (Schmitz C. \& Wagner T. , 2007, p. 5). The distribution channels refer to internal channels (like sales through internet and telephone) and external channels like retailers, partners, distributors, resellers, commercial alliances, suppliers etc. (Munusamy J. \& Chelliah Sh. , 2011, p. 2). All countries have laws that regulate marketing's activities in promoting, developing products, labeling, prices and distribution channels (Cateora PH \& Gilly M. \& Graham J 2011, p. 204). The marketing strategies of the company have to be responsible for the changes in the distribution channels between countries. This may require the delegation of marketing functions beyond the national affiliates (http: //www. att. com, p. 389).

\section{The design of international channels}

In order to support the growth of international market and the integration of economic activities in the world, it is crucial to have an effective distribution with effective cost. The challenge with the global management of distribution is to structure a responsible supply chain, enough flexible to confront the changes is customers demand and to enable the benefits of the production, focused on the objectives that must be achieved (Osman L. \&Westgerd M. , 2008, p. 1). The design of the distribution channel includes the description of the existing distribution channel, by evaluating the environmental impact and other factors that affect the company by defining the needs of consumers and channel's objectives and the evaluation of alternatives to choose the mediators of marketing channels (Gudonaviciene R. \& Alljosiene S. 2008, P. 74). The modeling of marketing channels requires the analysis of consumer's needs, to set the objectives of the marketing channel, the identification of the main alternatives of the marketing channel and their evaluation (Kotler P, \& Amstrong G. , 2011, p. 351). Many companies want to follow the international sales through advanced communication, in the diplomacy aspect through business links, international agreements, and in the technology aspect as well, through telecommunication and transport, advanced communication by designing the channels for the international business (Laurvick J. 1999, p. 1). The design of channels through international perspectives should be seen as a development of alternative structures of channels for international distribution that are defined by the special approaches for international involvement of marketing. The foreign production asks from the corporations strategic considerations of the levels that go beyond the scope of channels design. Indirect exportation means that a firm sells its products in foreign markets, but doesn't have a separate division inside its organization, by not making a considerable effort in the field of international marketing. Direct exportation means that the producer takes direct initiative in the export and delegation of duties for others for direct export, to make market contacts, market research, training, physical distribution, to prepare the export documentation, prices and many other duties that will be taken by the department of export itself. The selection of an appropriate structure means to choose the best alternative for the distribution in foreign markets (Bert R. 2004 \& 2013). 


\section{The motivation of the local and international channel members}

Motivation is important so that the channel members will agree on acting as mediators, and share their commitment and sources for the producing lines. The key to an effective motivation is to understand the needs and problems of the channel members (Osman L. \& Ëestgerd M. , 2008, p. 11). The three main aspects of the motivation for channel members are: 1. The recognition of the needs and problems of channel members; 2 . To offer support to them in accordance with their problems and needs; 3. To ensure leadership through effective use of channel power (Bert R. 2004 \& 2013, p.). the relations between the channel members are an increasingly important source in creating competitive advantage (Björkman M. ,2011, p. 1).

\section{Research results}

In countries going through transition like Kosovo, we can note a degree of non-effectiveness of distribution channels. Therefore, in this context, in an advanced market economy the international channels of marketing are becoming more important. Kosovar enterprises are giving attention to building stabile relations between international and local members.

Table 1. The importance of international distribution channels

\begin{tabular}{|l|l|}
\hline \multicolumn{1}{|c|}{ The importance of international distribution channels for enterprises } & $\%$ \\
\hline Very much & $78.9 \%$ \\
\hline Average & $19 \%$ \\
\hline A little & $1.8 \%$ \\
\hline Not at all & $0.3 \%$ \\
\hline & $100 \%$ \\
\hline
\end{tabular}

Source: the evaluation of authors based on the research results

From the interviewed enterprises $78.9 \%$ of the respondents said that international channels are very important, $19 \%$ of them said that their importance is average, $1.8 \%$ said that they are a little important and and only $0.3 \%$ said that they don't matter at all.

Chart 1. The importance of international distribution channels

\section{The importance of international distribution channels for enterprises}

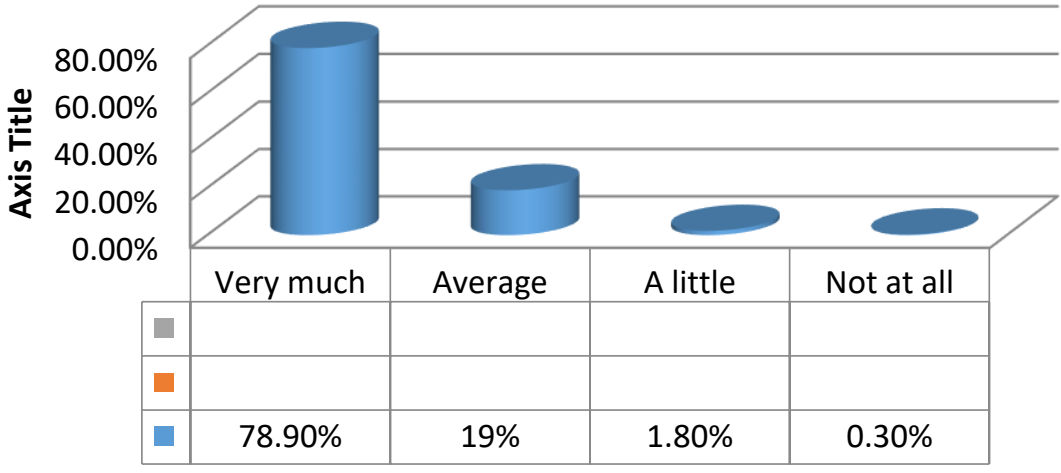


Source: the evaluation of authors based on the research results

Table 2 - The motivation of channel members as a factor of building strong relations between international and local members.

\begin{tabular}{|c|l|}
\hline $\begin{array}{c}\text { The motivation of channel members as a factor of building strong relations between } \\
\text { international and local members } \\
\text { Very much }\end{array}$ & $\%$ \\
\hline Average & $89.9 \%$ \\
\hline A little & $8 \%$ \\
\hline Not at all & $1.9 \%$ \\
\hline & $0.2 \%$ \\
\hline & $100 \%$ \\
\hline
\end{tabular}

Source: the evaluation of authors based on the research results

The motivation is an important factor for the channel members to reach agreement on acting as mediators, in order to share their engagement and the available resources. From the interviewed enterprises we notice that motivation has an impact on solving the problems between channel members. From the respondents, $89.9 \%$ said that the motivation of channel members is very important in building strong relations between international and local members, and only $0.2 \%$ said it didn't have any impact at all.

Chart 2. The motivation of channel members as a factor of building strong relations between international and local members

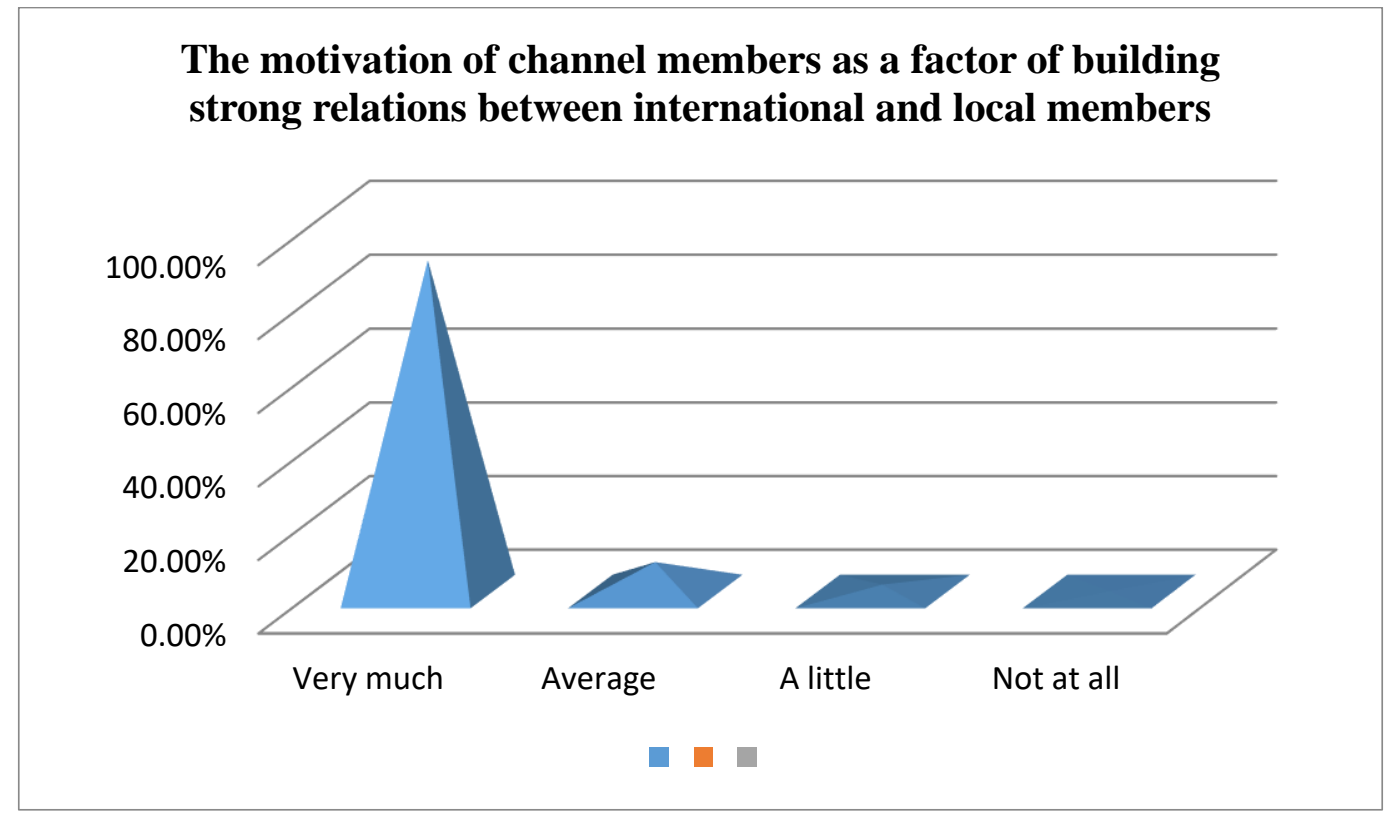

Source: the evaluation of authors based on the research results

The changes in the market's structure and the globalization of markets are issues that have attracted the attention of many enterprises that deal with distributing the goods and services inside and out of the country. 
Table 3. The streamlining of distribution and market's globalization

\begin{tabular}{|l|l|}
\hline The streamlining of distribution and market's globalization & $\%$ \\
\hline Free flow of information & $21.9 \%$ \\
\hline The increase of pressure to develop communication with the countries of the region and Europe & $17.9 \%$ \\
\hline $\begin{array}{l}\text { The increase of specialization of distribution channels for goods and serviced beyond the national } \\
\text { borders }\end{array}$ & $37.85 \%$ \\
\hline The opportunity to satisfy the client's needs & $22.4 \%$ \\
\hline & $100 \%$ \\
\hline
\end{tabular}

Source: the evaluation of authors based on the research results

From the table results we can see that the streamlining of distribution for the kosovar enterprises in $37.85 \%$ has brought higher specialization in the level of the distribution of goods and services through national and international borders, 22. $4 \%$ could satisfy they client's needs and, $21.9 \%$ have increased the free flow of information, $17.9 \%$ have increased the pressure to develop communication with the countries of the region and Europe.

Chart 3. The streamlining of distribution and market's globalization

\section{The streamlining of distribution and market's globalization}

The opportunity to satisfy the client's needs The increase of specialization of.. The increase of pressure to develop.. Free flow of information

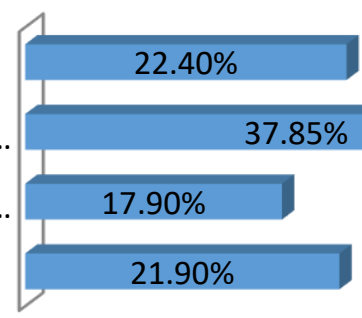

Source: the evaluation of authors based on the research results

Many Kosovar enterprises have profited from their experience in the international marketing field that has had a positive impact in designing strategies and tactics of development plans in the field of distribution.

Table 4. The challenges of managing international business

\begin{tabular}{|l|l|}
\hline The challenges of managing international business & $\%$ \\
\hline The direct investment in other countries & $17.9 \%$ \\
\hline The engagement of business in multinational enterprises integrated in global economies & $34.6 \%$ \\
\hline Gain experience in the field of international marketing & $18.8 \%$ \\
\hline The change of strategies and tactics of marketing & $28.7 \%$ \\
\hline & $100 \%$ \\
\hline
\end{tabular}


Source: the evaluation of authors based on the research results

From the table we can see that for $34.6 \%$ of the interviewed enterprises the main challenge of managing the business is the engagement of business in multinational enterprises integrated in global economies, for $28.7 \%$ the main challenge is the change of strategies and tactics of marketing, for $18.8 \%$ it is the to gain experience in the field of international marketing and for $17.9 \%$ it is the direct investment for operations in other countries.

Chart 4. The challenges of managing international business

\section{The challenges of managing international business}

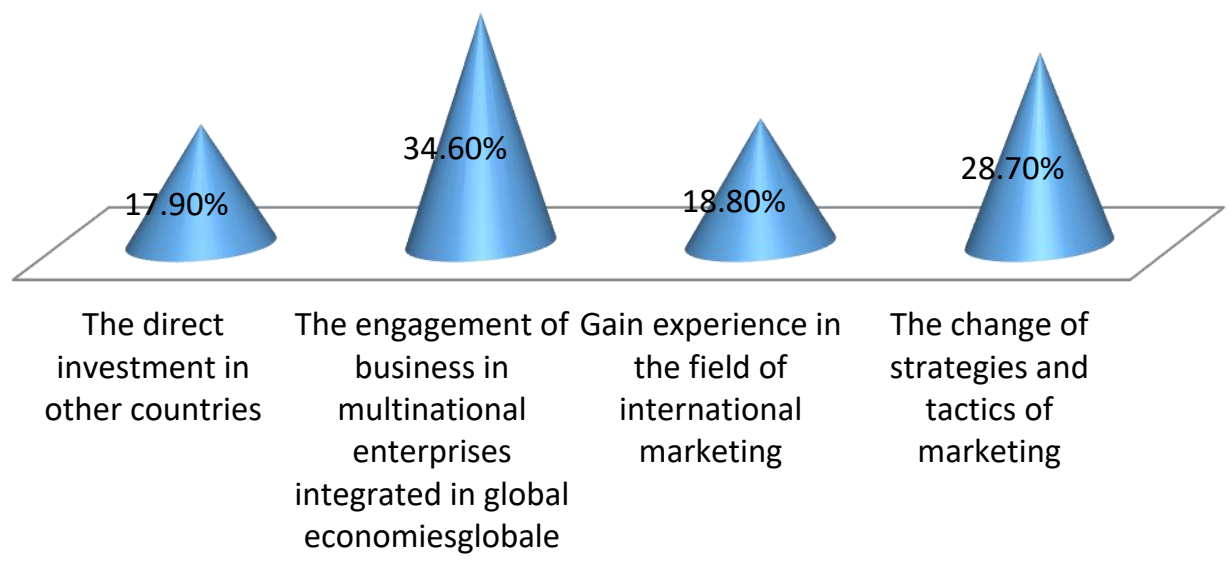

Source: the evaluation of authors based on the research results

From the interviewed enterprises we can see that the organization of sales is realized through telephone and internet, retailers, wholesalers, distributors and market alliances.

Table 5. The design of distribution channels through international perspectives and international distribution

\begin{tabular}{|l|l|}
\hline $\begin{array}{l}\text { The design of distribution channels through international perspectives and international } \\
\text { distribution }\end{array}$ & $\%$ \\
\hline The development of alternative structures of channels for international distribution & $12.8 \%$ \\
\hline Special approaches for international involvement of marketing required by the firm & $18.9 \%$ \\
\hline Strategic considerations that go beyond the scope of channel's design & $25.9 \%$ \\
\hline Market links & $7.9 \%$ \\
\hline International agreements on technology, telecommunication and transport & $28.4 \%$ \\
\hline Advanced communication & $6.1 \%$ \\
\hline & $100 \%$ \\
\hline
\end{tabular}

Source: the evaluation of authors based on the research results

Based on the table we can see that $28.4 \%$ of the kosovar enterprises see the design of distribution channels from the international perspectives as an international agreement in the aspect of technology, telecommunication and transport, 25. 
$9 \%$ see it as a strategic consideration that goes beyond the scope of channel's design, $18.9 \%$ see it as a special approach for international involvement of marketing required by the firm.

Chart 5. The design of distribution channels through international perspectives and international distribution

\section{The design of distribution channels through international perspectives and international distribution}

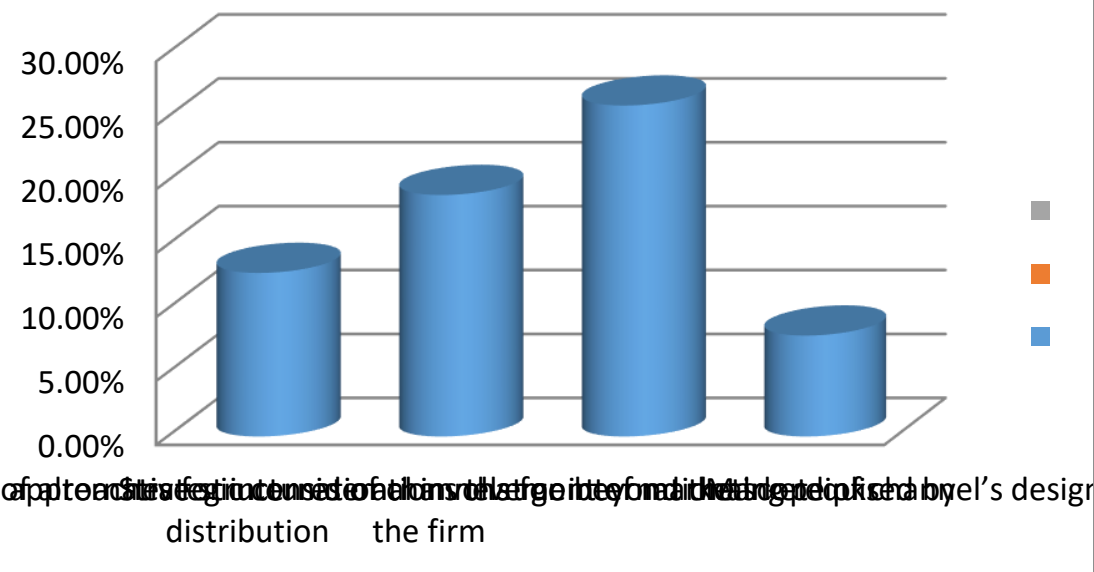

Source: the evaluation of authors based on the research results

\section{Conclusions and recommendations}

The international marketing include business activities designed to plan, to stir up fares, to direct the goods and services of the company for the consumers in the international level. At the other extreme, the distribution channels at countries in development can be spread, not effective or don't exist at all. Therefore it is a challenge of business management to develop effective cooperation between channel systems in national and international markets and the integration of enterprises in global economies. We recommend further research on designing distribution channels in national and international levels and the creation of a guide for the development of marketing strategies from the producers. The use of many types of resellers in a channel, by using transversal and direct international channels and the design of the strategy for the management of conflicts in the channel and the modeling and design of international distribution channels.

It is recommended for the kosovar enterprises to raise the opportunities to:

- Higher specialization in the level of distribution;

- Wider communication between the countries of the region and Europe;

- The dissemination of information that would enable the free flow of goods through national and international borders;

- Reorganization of distribution and the globalization of markets;

- The design of distribution channels through international perspectives. 


\section{References}

[1] Bert R. (2004 \& 2013) Marketing cheannels- Drexel University, Thomson, South -western Björkman M. ,2011, "Investigating Channel Push Branding" The Case of Konftel, Umeå School of Business

[2] Cateora PH \& Gilly M. \& Graham J (2011)," International marketing "15th ed. , p. cm.

[3] Gudonaviciene R. \& Alljosiene S. (2008), "The Specific Features of Marketing Channel Design" ISSN 13922785 ENGINEERING ECONOMICS. 2008. No 1 (56) ECONOMICS OF ENGINEERING DECISIONS Includes index.

[4] Kotler P, \& Amstrong G. , (2011), Principles of Marketing, 14th Edition, Pearson Prentice Hall

[5] Laurvick J. 1999, "Channel Management"- Gaining perspective for global distribution, International Business 470 School of Business and Administration University of Washington.

[6] Mühlbacher H. \& Leihs H. \& Dahringerp L. , (2006)," International Marketing: A Global Perspective, Third Edition, High Holborn House 50-51 Bedford Row London WC1R 4LR

[7] Munusamy J. \& Chelliah Sh. , 2011, "INTERNATIONAL DISTRIBUTION STRATEGY: A CASE STUDY IN MALAYSIA", Business and Management Review 1 (1): 1-18, March, 2011,

[8] Onkvisit S. \& Shaw J. 2004, "International Marketing" Analysis and strategy, Fourth edition, Simultaneously published in the UK, USA and Canada by Routledge 29 West 35th Street, New York, NY 10001 and by Routledge 11 Neë Fetter Lane, London EC4P 4EE

[9] Osman L. \& Westgerd M. , 2008, "International distribution channels"- from the perspective of exporting companies, Luleå University of Technology.

[10] Schmitz C. \& Wagner T. , 2007, p. 5 "Satisfaction in International Marketing Channels: A Local Channel Member Perspective" Journal of Marketing Channels, Vol. 14 (4) 2007 Available online at http: //jmc. haworthpress. com

[11] Segetlija Z. \& Mesarić J. \& Dujak D. ,2011" IMPORTANCE OF DISTRIBUTION CHANNELS - MARKETING CHANNELS - FOR NATIONAL ECONOMY" University of J. J. Strossmayer, Faculty of Economics in Osijek 